\title{
Relationship Among the Symptom Severity of Knee Osteoarthritis, Quality of Life and Sleep Quality
}

\section{Diz Osteoartriti Semptom Şiddeti, Yaşam Kalitesi ve Uyku Kalitesi Arasındaki İlișki}

\author{
Sevgi İkbali Afsar ${ }^{1}$, Hüma Bölük $k^{1}$, Selin Özen ${ }^{1}$
}

'Başkent University, Faculty of Medicine, Department of Physical Medicine and Rehabilitation, Ankara

\begin{abstract}
Objectives: Knee osteoarthritis $(\mathrm{OA})$ is a widespread disease that increases in the elderly and is an important cause of morbidity. It is common knowledge that resting and nocturnal pain is rarely seen in patients with knee OA, however latest studies showed that it is not rare. Sleep disorders are thought to be related with nocturnal pain and it is shown that in patients with arthritis are more likely to develop sleep problems. Nocturnal pain is also related with depression and decreased quality of life. This study aims to evaluate sleep quality in patients with knee OA and to reveal the relationship between severity of knee OA, pain and sleep disorders and quality of life in female and male patients.

Materials and Methods: This cross sectional study includes 41 volunteer patients ( 27 female,14 male) between 40-65 years with knee OA, who suffer from knee pain for more than 6 months, and the study includes patients with grade 2 and $3 \mathrm{OA}$ according to the Kellgren-Lawrence classification. Patients were evaluated using Visual Analog Scale (VAS), Western Ontario and McMaster Universities Osteoarthritis Index (WOMAC), Lequesne Index, Pittsburg Sleep Quality Index (PSQI), Beck Anxiety Inventory (BAI), Beck Depression Inventory (BDI) and Short form-36 (SF-36).

Results: VAS, WOMAC, Lequesne index, PSQI, BAI and BDI scores were significantly higher in female subjects than in male subjects. Prevalence of good sleep quality was significantly higher in male patients. There was a positive correlation between WOMAC scores and VAS, BAI and BDI scores, but there was no significant relationship between total PSQI scores. There was a positive correlation between Lequesne index scores and VAS, total PSQI, BAI and BDI scores. A negative correlation was found between WOMAC and Lequesne index and SF-36.

Conclusion: Severity of knee OA is found associated with pain, depression and anxiety, sleep quality and quality of life. It should be considered to manage knee OA to improve quality of life.

Keywords: Knee osteoarthritis, pain, sleep quality, quality of life
\end{abstract}

\section{$\ddot{O} \mathbf{z}$}

Amaç: Diz osteoartriti (OA), yaşla sıklığı artan yaygın bir hastalıktır ve önemli bir morbidite nedenidir. Diz OA'lı hastalarda istirahat ve nokturnal ağrının nadiren görüldüğü yaygın bir bilgidir, ancak son çalışmalar nadir görülmediğini göstermiştir. Uyku bozukluklarının noktürnal ağrı ile ilișkili olduğu düşünülür ve artritli hastalarda uyku problemleri gelişmesi daha olasıdır. Gece ağrısı aynı zamanda depresyon ve yaşam kalitesinin düșmesi ile de ilişkilidir. Bu çalışmada, diz OA'lı hastalarda uyku kalitesini değerlendirmek ve OA șiddetiyle ağrı ve uyku bozuklukları ile kadın ve erkek hastalarda yaşam kalitesi arasındaki ilişkiyi ortaya koymak amaçlanmıștır.

Materyal ve Metot: Bu kesitsel çalıșma diz OA'sı olan 41 gönüllü hastayı (27 kadın, 14 erkek) kapsamakta ve 40-65 yaș arası 6 aydan fazla diz ağrısı olan ve Kellgren-Lawrence 'e göre 2. ve 3. derece olan hastaları kapsamaktadır. Hastalar Görsel Analog Skala (GAS), Western Ontario and McMaster Universitesi Osteoartrit İndeksi (WOMAC), Lequesne Indeksi, Pittsburg Uyku Kalitesi İndeksi (PSQI), Beck anksiyete envanteri (BAI), Beck depresyon envanteri (BDI) ve Kısa form-36 (SF-36) kullanılarak değerlendirildi.

Bulgular: VAS, WOMAC, Lequesne indeksi, PSQI, BAI ve BDI skorları kadınlarda erkeklere göre anlamlı olarak yüksek bulundu. Erkeklerde iyi uyku kalitesi prevalansı anlamlı olarak yüksek bulundu. WOMAC skorları ile VAS, BAI ve BDI skorları arasında pozitif bir korelasyon vardı, fakat toplam PSQI skoru arasında anlamlı bir ilişki yoktu. Lequesne indeks skorları ile VAS, total PSQI, BAI ve BDI skorları arasında pozitif korelasyon vardı. WOMAC ve Lequesne indeksi ile SF-36 arasında negatif korelasyon bulundu. 
Sonuç: Sonuç olarak, diz OA semptom şiddeti ile depresyon, anksiyete, uyku kalitesi ve yaşam kalitesi ilişkili bulunmuştur. Yaşam kalitesini iyileştirmek için diz OA'yı yönetmek düşünülmelidir.

Anahtar kelimeler: Diz osteoartriti, ağrı, uyku kalitesi, yaşam kalitesi

Correspondence / Yazışma Adresi:

Dr. Sevgi Ikbali Afşar

Başkent University Faculty of Medicine, Department of Physical Medicine and Rehabilitation, Ankara

e-mail: ikbaliafsar@hotmail.com

Date of submission: 13.08 .2018

Date of admission: 22.10 .2018

\section{Introduction}

Knee Osteoarthritis (OA) is one of the most common musculoskeletal disorders presented with pain and joint stiffness. The frequency of knee OA increases with age and obesity with a prevalance of $2 \%$ between the ages of $30-40,8 \%$ between the ages of 41-50 and $21 \%$ between the ages of $51-74 .{ }^{1}$ With an increase in life expectancy, knee OA has become a greater public health problem due to its detrimental effects on joint mobility and quality of life.

It is commonly known that resting and nocturnal pain is rarely seen in patients with knee OA. However, some studies have shown that nocturnal pain occurs frequently and has been reported in $81 \%$ of patients with knee OA..$^{2-5}$ Sleep disorders are thought to be related to nocturnal pain; it has been shown that inflammatory arthritic patients are more likely to develop sleep problems; however, it has also been reported that sleep disorders are associated with pain. ${ }^{4}$ In another study, the nocturnal pain was present in $40 \%$ of patients with severe knee OA and it was shown that it affected sleep quality and decreased the quality of life. ${ }^{6}$

Studies to date have shown that OA patients also suffer from depression and a worsening of quality of life. In Turkey, the prevalence of depression in knee OA patients is higher than the population average at $41 \%$ and has been associated with pain and immobility. ${ }^{7,8}$

This study aims to evaluate the sleep quality in patients with knee OA and to reveal the relationship among severity of knee OA, pain and sleep disorders and quality of life in female and male patients.

\section{Materials and Methods}

\section{Subjects}

This cross-sectional study included 41 ( 27 female,14 male) patients between the ages of 40-65 with knee OA, admitted to Başkent University, Physical Medicine and Rehabilitation outpatient clinic between December 2015- April 2016 with an history of knee pain for more than six months. Patients with stage 2 and 3 OA according to the Kellgren-Lawrence (KL) grading scale, who were diagnosed with knee OA according to the American College of Rheumatology (ACR), were included in the study. ${ }^{9,10}$ Patients with an history of ankle and hip problems or knee operations, rheumatic disease, metabolic bone disorders, chronic kidney or heart disease, neurological disease and chronic depression or those currently on antidepressants, those who received physical therapy or underwent intraarticular interventions within the last 6 months were excluded. 
The study was approved by the ethical committee of Başkent University School of Medicine prior to commencement. Informed consent was obtained from all patients.

\section{Evaluation}

The assessments of all the patients were made by the same physician in the outpatient clinic. Demographic and clinical characteristics such as gender, age, marital status, educational status, systemic disease presence were recorded. Physical examinations of the patients were performed, heighst and weights were measured, body mass indices were calculated as $\mathrm{kg} / \mathrm{m}^{2}$.

Radiological evaluation: Bilateral anteroposterior views of the participants were graded according to the KL scale. In this grading system; KL grade 1 is doubtful osteophyte, grade 2 is definite osteophyte, with normal joint space, grade 3 is definite osteophyte with narrowing of joint space and grade 4 is definite osteophyte with marked narrowing of joint space, severe sclerosis, and definite bone deformity. ${ }^{9}$ The worse side was chosen for grading. Same physician made the classifications and only the patients with grade 2 and 3 knee OA were incorporated in the study.

Visual Analog Scale: $10-\mathrm{cm}$ visual analog scale (VAS) was used by patients to perform a self-assessment of pain intensity associated with knee OA."

Western Ontario and McMaster Universities Osteoarthritis Index: Western Ontario and McMaster Universities Osteoarthritis Index (WOMAC) were used to evaluate the intensity of pain, stiffness, and level of function associated with knee OA. ${ }^{12,13}$ This index consists of 5 questions for pain, 2 questions for stiffness and 17 questions for physical function.

Lequesne Index: The Lequesne index was used to determine the severity of knee OA. This index analyzes pain, maximum walking distance, and activities of daily living. The score obtained increases with OA severity. ${ }^{14}$ This survey has been shown to be valid and reliable in patients with knee OA and in Turkish patients. ${ }^{15,16}$

Pittsburgh Sleep Quality Index: Sleep quality was evaluated using the Pittsburgh Sleep Quality Index (PSQI). This index consists of subjective sleep quality, sleep latency, sleep duration, habitual sleep efficiency, sleep disturbances, sleep disorders, use of sleep medications and daytime dysfunction components. PSQI assesses the symptoms of the last 4 weeks. Higher scores show insufficient sleep and lower sleep quality. ${ }^{17,18}$ Short Form-36: Short form-36 (SF-36) was used to assess health-related quality of life. $\mathrm{SF}-36$ is a brief and easily administered questionnaire. It consists of 36 questions and two subgroups; mental and physical assessment. Scores range from o-100, 100 denotes the highest level of health, o denotes the worst. The SF-36 questionnaire was adapted for the Turkish population and found valid and reliable in osteoarthritis patients. ${ }^{19}$

Beck Depression Inventory: Beck Depression Inventory (BDI) was used to evaluate the characteristics of depression and anxiety. BDI consists of 21 questions, higher scores imply increased depression symptom severity. ${ }^{20}$

Beck Anxiety Inventory: Beck Anxiety Inventory (BAI) is a self-reporting scale which was performed to assess the anxiety frequency and severity in patients. The BAI consists of 21 questions. The high scores on the scale indicate that the severity of anxiety experienced by the individual is high. ${ }^{21}$ 


\section{Statistical analysis}

Statistical analysis was performed using SPSS for Windows version 20 (IBM SPSS Inc., Chicago, IL). Normal distribution of the data was evaluated using the KolmogorovSmirnov test. Normally distributed quantitive data were expressed as mean \pm standard deviations (SD) and non-normally distributed quantitive data were shown as median (min-max). Values for categorical variables were given in numbers and percentages. The Mann Whitney $U$ and student t-tests were used in order to determine data correlation between the two groups. Categorical data were compared using the Chisquare and Fisher's Exact Test. Correlation between severity of OA and BDI, SF-36 and total PSQI scores were determined using the Spearmen's correlation analysis. To determine the factors related to the severity of OA, stepwise multivariate logistic regression analysis was performed using the BDI, SF-36 and PSQI scores. Adjustment for non-normally distributed quantitive data including WOMAC, Lequesne index, VAS, PSQI, BDI and BAI variables was made prior to regression analysis. A $p$ value less than 0.05 was considered to be statistically significant.

\section{Results}

Demographic and clinical characteristics of the patients are given in Table 1 . There was no significant difference in terms of age and body mass index among male and female patients.

Table 1. Demographic and clinical characteristics of patients

\begin{tabular}{|l|c|}
\hline Variables & Result \\
\hline Sex (female), $\mathrm{n}(\%)$ & $27(65.85 \%)$ \\
\hline Age, years (mean \pm SD) & $61.11 \pm 12.02$ \\
\hline BMI, kg/m ${ }^{2}$ (mean \pm SD) & $27.63 \pm 3.54$ \\
\hline Marital status, $\mathrm{n}(\%)$ & $8(19.51 \%)$ \\
\hline Single/divorced/widoved & $33(80.48 \%)$ \\
\hline Married & $8(19.51 \%)$ \\
\hline Education level, $\mathrm{n}(\%)$ & $19(46.34 \%)$ \\
\hline Elementary school & $14(34.14 \%)$ \\
\hline High school & $11(26.83 \%)$ \\
\hline Collage graduate & $15(36.58 \%)$ \\
\hline Working status, $\mathrm{n}(\%)$ & $15(36.58 \%)$ \\
\hline Employment & $5.79(1-31)$ \\
\hline Retired & $21(51.22 \%)$ \\
\hline Homemaker & \\
\hline Duration of knee OA (years)(min-max) & $18(43.90 \%)$ \\
\hline Presence of multiple drug use, $\mathrm{n}(\%)$ & $18(43.90 \%)$ \\
\hline Physical activity, n (\%) & $5(12.19 \%)$ \\
\hline Not & \\
\hline Sometimes & \\
\hline Regular & \\
\hline
\end{tabular}

Values are mean \pm standard deviation, minimum to maximum, $\mathrm{n}(\%)$.

SD: Standart deviation; BMI: Body mass index; OA: Osteoarthritis 
VAS (7 vs 5; $\mathrm{p}=0.008$ ), WOMAC ( 51 vs 22.4; $\mathrm{p}=0.013$ ), Lequesne index (13 vs 5.5; $\mathrm{p}=0.005$ ), total PSQI (6 vs 2 ; $\mathrm{p}=0.001$ ), BAI (17 vs 6; $\mathrm{p}=0.002$ ) and BDI scores (11 vs 4.5; $\mathrm{p}=0.003$ ) were significantly higher in female subjects than in male subjects (Table 2).

Table 2. Clinical characteristics of patients

\begin{tabular}{|c|c|c|c|c|}
\hline & $\begin{array}{c}\text { Patients } \\
n=41\end{array}$ & $\begin{array}{c}\text { Female } \\
\mathbf{n}=\mathbf{2} 7\end{array}$ & $\begin{array}{c}\text { Male } \\
\mathrm{n}=14\end{array}$ & $\mathbf{p}$ \\
\hline VAS & $6(0-10)$ & $7(4-10)$ & $5(0-7)$ & $0.008^{*}$ \\
\hline WOMAC & $36.50(2.11-93.79)$ & $51(11.49-93.82)$ & $22.40(2.12-59.42)$ & $0.013^{*}$ \\
\hline Lequesne index & $10(1-20)$ & $13(5-20)$ & $5 \cdot 51(1-16)$ & $0.005^{*}$ \\
\hline PSQI & $5(1-14)$ & $6(1-14)$ & $2(1-6)$ & $0.001^{*}$ \\
\hline $\mathrm{SF}-36$ & $91.84 \pm 8.34$ & $90 \pm 7.5^{2}$ & $95.22 \pm 9$ & 0.055 \\
\hline BAI & $13(0-38)$ & $17(1-38)$ & $6(0-19)$ & $0.002^{*}$ \\
\hline BDI & $9(0-40)$ & $11(0-40)$ & $4.52(0-15)$ & $0.003^{*}$ \\
\hline
\end{tabular}

VAS: Visual analog scale; WOMAC: Western Ontario and McMaster Universities Osteoarthritis Index; PSQI: Pittsburgh Sleep Quality Index; SF-36: Short form-36; BAI: Beck anxiety inventory; BDI: Beck depression inventory.

Values are mean \pm standard deviation, minimum to maximum, $\mathrm{n}(\%)$.

${ }^{*} \mathrm{p}<0.05$ is considered to be statistically significant.

Prevalance of good sleep quality was significantly higher in male patients ( $40.69 \%$ to 92.88\%; $\mathrm{p}=0.002$ ). Prevalance of very good sleep latency (the subgroup of PSQI) was higher in male patients when compared to female patients ( $14.81 \%$ vs $85.72 \%$; $p<0.001$ ); however, there was no difference in values between male and female patients for any other PSQI subgroups (Table 3 ).

Table 3. Distribution of sleep quality scores in patients with knee osteoarthritis

\begin{tabular}{|c|c|c|c|c|}
\hline & $\begin{array}{c}\text { Patients } \\
n=41\end{array}$ & $\begin{array}{c}\text { Female } \\
\mathbf{n}=27\end{array}$ & $\begin{array}{l}\text { Male } \\
\mathrm{n}=14\end{array}$ & $\mathbf{p}$ \\
\hline Total PSQI score & $5(1-14)$ & $6(1-14)$ & $2(1-6)$ & $0.001^{*}$ \\
\hline Good sleep quality & $24(58.31)$ & 11 (40.69) & $13(92.92)$ & \multirow{2}{*}{$0.002^{*}$} \\
\hline Poor sleep quality & $17(41.69)$ & $16(59.31)$ & $1(7.08)$ & \\
\hline \multicolumn{5}{|l|}{ Sleep disturbances } \\
\hline Very good & - & - & - & \multirow{4}{*}{0.133} \\
\hline Fairly good & $25(61.00)$ & $14(51.90)$ & $11(78.59)$ & \\
\hline Fairly bad & $14(34.11)$ & $12(44.39)$ & $2(14.31)$ & \\
\hline Very bad & $2(4.89)$ & $1(3.69)$ & $1(7.10)$ & \\
\hline \multicolumn{5}{|l|}{ Sleep latency } \\
\hline Very good & $16(39.01)$ & $4(14.82)$ & $12(85.70)$ & \multirow{4}{*}{$<0.001^{*}$} \\
\hline Fairly good & $15(36.61)$ & $15(55.61)$ & - & \\
\hline Fairly bad & $7(17.09)$ & $6(22.19)$ & $1(7.10)$ & \\
\hline Very bad & $3(7.29)$ & $2(7.38)$ & $1(7.10)$ & \\
\hline \multicolumn{5}{|l|}{ Daytime dysfunction } \\
\hline Very goog & $24(58.51)$ & $13(48.13)$ & $11(78.60)$ & \multirow{3}{*}{0.242} \\
\hline Fairly good & $12(29 \cdot 31)$ & $10(37.03)$ & $2(14.31)$ & \\
\hline Fairly bad & $3(7.28)$ & $2(7.36)$ & $1(7.09)$ & \\
\hline
\end{tabular}




\begin{tabular}{|c|c|c|c|c|}
\hline Very bad & $2(4.90)$ & $2(7 \cdot 38)$ & - & \\
\hline \multicolumn{5}{|l|}{$\begin{array}{l}\text { Habitual sleep } \\
\text { efficiency }\end{array}$} \\
\hline Very good & $29(70.66)$ & $16(59.32)$ & $13(92.89)$ & \multirow{4}{*}{0.189} \\
\hline Fairly good & $8(19.54)$ & $7(25.93)$ & $1(7.11)$ & \\
\hline Fairly bad & $2(4.89)$ & $2(7 \cdot 35)$ & - & \\
\hline Very bad & $2(4.89)$ & $2(7.35)$ & - & \\
\hline \multicolumn{5}{|c|}{ Subjective sleep quality } \\
\hline Very good & $6(14 \cdot 59)$ & $3(11,10)$ & $3(21.39)$ & \multirow{4}{*}{0.088} \\
\hline Fairly good & $28(68.31)$ & $17(63.0)$ & $11(78.61)$ & \\
\hline Fairly bad & $7(17.10)$ & $7(25.90)$ & - & \\
\hline Very bad & - & - & - & \\
\hline \multicolumn{5}{|l|}{$\begin{array}{l}\text { Use of sleeping } \\
\text { medication }\end{array}$} \\
\hline Very good & $39(95.12)$ & $25(92.61)$ & $14(100.00)$ & \multirow{4}{*}{0.539} \\
\hline Fairly good & - & - & - & \\
\hline Fairly bad & - & - & - & \\
\hline Very bad & $2(4.88)$ & $2(7.39)$ & - & \\
\hline
\end{tabular}

Values are mean \pm standard deviation, minimum to maximum, $\mathrm{n}(\%)$.

${ }^{*} \mathrm{p}<0.05$ is considered to be statistically significant.

There was a positive correlation among WOMAC and VAS ( $\mathrm{r}=0.372 ; \mathrm{p}=0.017)$, BAI $(\mathrm{r}=0.492 ; \mathrm{p}=0.001)$ and $\mathrm{BDI}(\mathrm{r}=0.384 ; \mathrm{p}=0.013)$ scores. There was a negative correlation between WOMAC and SF-36 scores $(\mathrm{r}=-0.458 ; \mathrm{p}=0.003)$. There was no significant relationship between total PSQI scores and WOMAC scores (Table 4).

There was a positive correlation among Lequesne index scores and VAS $(\mathrm{r}=0.502$; $\mathrm{p}=0.001)$, total PSQI $(\mathrm{r}=0.451 ; \mathrm{p}=0.003)$, BAI $(\mathrm{r}=0.485 ; \mathrm{p}=0, .01)$, and BDI $(\mathrm{r}=0.590$; $\mathrm{p}<0.001)$ scores. There was a negative correlation between Lequesne index and SF-36 scores $(\mathrm{r}=-0.617 ; \mathrm{p}<0.001)$ (Table 4$)$.

Table 4. Relations between osteoarthritis severity and pain, depression, quality of life and sleep quality

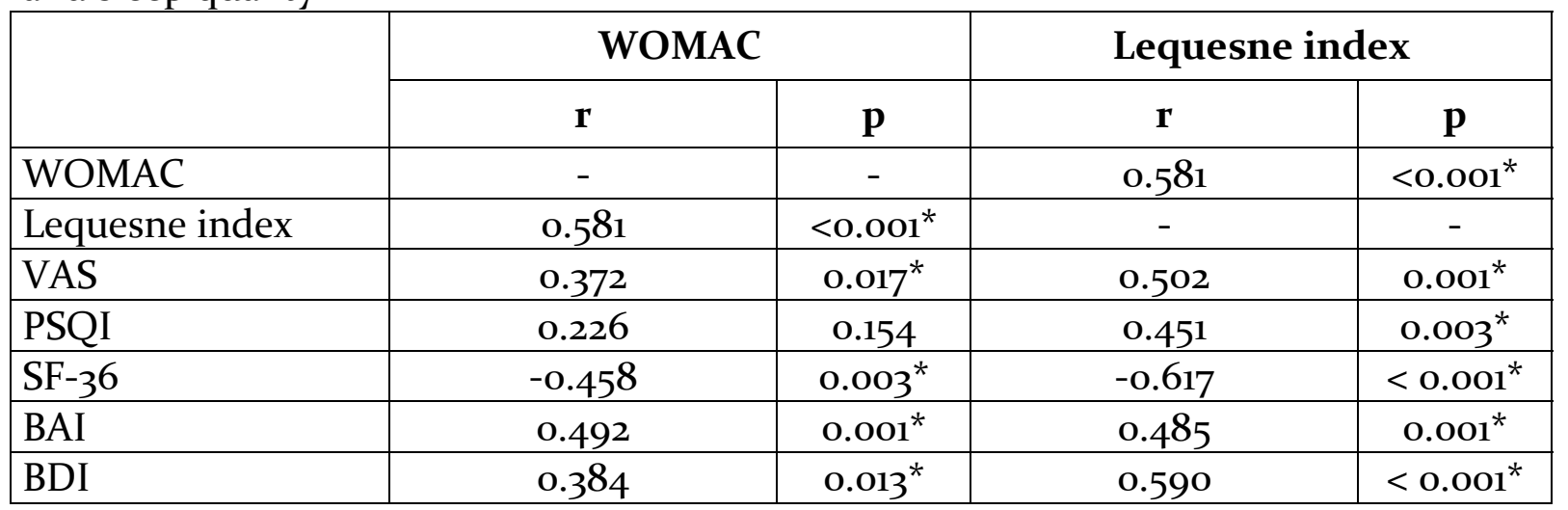

VAS: Visual analog scale; WOMAC: Western Ontario and McMaster Universities Osteoarthritis Index; PSQI: Pittsburgh Sleep Quality Index; SF-36: Short form-36; BAI: Beck anxiety inventory; BDI: Beck depression inventory.

${ }^{*} \mathrm{p}<0.05$ is considered to be statistically significant. 
VAS $(\beta \pm S E=3.174 \pm 1.390 ; p=0.028), S F-36(\beta \pm S E=-0.913 \pm 0.388 ; p=0.024)$ and BAI $(\beta \pm S E$ $=1.336 \pm 0.405 ; \mathrm{p}=0.002)$ scores were determined as possible predictor variables for WOMAC scores (Table 5).

Table 5. Factors related knee osteorthritis severity

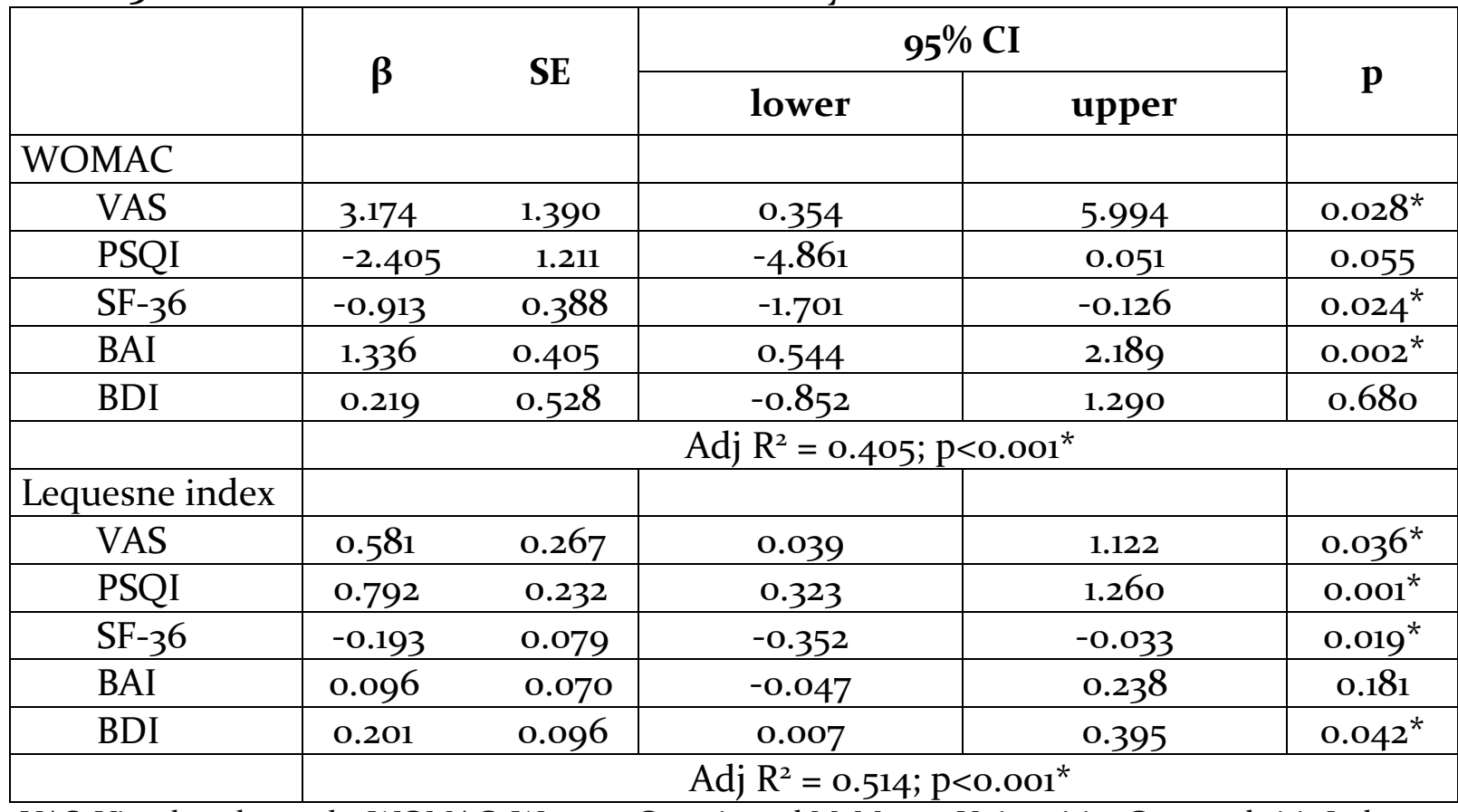

VAS: Visual analog scale; WOMAC: Western Ontario and McMaster Universities Osteoarthritis Index; PSQI: Pittsburgh Sleep Quality Index; SF-36: Short form-36; BAI: Beck anxiety inventory; BDI: Beck depression inventory.

$\beta=$ Regression coefficient, SE:Standart error, $95 \% \mathrm{CI}=95 \%$ Confidence interval,

Adj: Adjusted

${ }^{*} \mathrm{p}<0.05$ is considered to be statistically significant.

$\operatorname{VAS}(\beta \pm S E=0.581 \pm 0.267 ; p=0.036), B D I(\beta \pm S E=0.201 \pm 0.096 ; p=0.042), S F-36(\beta \pm S E=-$ $0.193 \pm 0.079 ; \mathrm{p}=0.019)$ and total PQSI scores $(\beta \pm \mathrm{SE}=0.792 \pm 0.232 ; \mathrm{p}=0.001)$ were determined as possible variables for Lequesne index scores (Table 5).

\section{Discussion}

The aim of this study was to investigate the relationship among OA severity, depression, sleep quality and quality of life in patients with knee OA. The results show that the females have worse pain, symptom severity, depression, and sleep quality scores in comparison to the male patient. On the other hand, there is no significant difference between male and female subjects when comparing the quality of life scores. Higher knee OA symptom severity scores are associated with worse pain, sleep quality, quality of life and higher depression-anxiety scores.

Prior studies revealed that depression, pain, and disability due to OA were worse in female patients than in male patients. The difference between genders is thought to be associated with different anatomical structures, sex hormones, and psycho-social factors. ${ }^{22-25}$ Similarly in our study, pain, disability and depression scores, as defined by questionnaires, were higher in the female patients. In addition, according to our 
findings, the prevalence of good sleep quality and good sleep latency was higher in males than in female patients. This is also the case in the general population. ${ }^{26}$

Previously, it has been reported that $49.3 \%$ of patients with knee OA have depressive symptoms. ${ }^{6}$ Another study found a negative correlation between physical function and depression in knee OA patients. ${ }^{25}$ The findings of this study were consistent with these previous findings, with a positive correlation between Lequesne scores, a questionnaire which is mostly associated with disability and depression. WOMAC scores were related to anxiety. However, in contrast to our findings, Creamer et al. showed that disability is related to anxiety more than depression in knee OA patients. ${ }^{27}$

There was no correlation between WOMAC scores and sleep quality; however, Lequesne scores were significantly associated with sleep quality. Previously, both pain and functional disability were associated with sleep disorders. ${ }^{8}$ In the present study, our findings support the belief that disability is related to sleep disorders due to the correlation between Lequesne scores and sleep quality index scores. The study of Mesci et al. did not show WOMAC for symptom severity, and the physically active group did not show any difference in the comparison of sleep quality. ${ }^{7}$ This is similar to our findings.

In a report that investigated the impact of neuropathic pain in knee OA, it has been shown that severity of knee OA, defined using WOMAC scores, were related to the worse quality of life in patients that were both detected to have neuropathic pain and those that did not. ${ }^{28}$ The findings of this study concur with this finding.

There were several limitations to this study. The number of patients was limited and an age-matched control group was not included. Sleep quality index was self-reported, which could lead to the reporting of subjective sleep disturbances due to pain. Lastly, the demographic variation could result in different perceptions of pain.

In conclusion, in the light of these findings, knee OA severity is associated with pain, depression, and anxiety, as well as sleep quality and quality of life. Therefore management of knee OA should be considered with every effort in order to improve the quality of life.

\section{References}

1. Pavelka K, Gatterova J, Altman RD. Radiographic progression of knee osteoarthritis in a Czech cohort. Clin Exp Rheumatol 2000;18: 473-7.

2. Woolhead G, Gooberman-Hill R, Dieppe P, Hawker G. Night pain in hip and knee osteoarthritis: a focus group study. Arthritis Care Res (Hoboken) 2010;62: 944-9.

3. Hawker GA, Stewart L, French MR, et al. Understanding the pain experience in hip and knee osteoarthritis--an OARSI/OMERACT initiative. Osteoarthritis Cartilage 2008;16: 415-22.

4. Power JD, Perruccio AV, Badley EM. Pain as a mediator of sleep problems in arthritis and other chronic conditions. Arthritis Rheum 2005;53: 911-9.

5. Abad VC, Sarinas PS, Guilleminault C. Sleep and rheumatologic disorders. Sleep Med Rev 20o8;12: 211-28.

6. Sasaki E, Tsuda E, Yamamoto Y, et al. Nocturnal knee pain increases with the severity of knee osteoarthritis, disturbing patient sleep quality. Arthritis Care Res (Hoboken) 2014;66: 1027-32.

7. Mesci E, Icagasioglu A, Mesci N, Turgut ST. Relation of physical activity level with quality of life, sleep and depression in patients with knee osteoarthritis. North Clin Istanb 2015;2: 215-21.

8. Küçükşen S, Yılmaz H, Karahan AY, Bağçacı S. The prevalence of depression and its relevance to clinical and radiological characteristics among older adults with knee osteoarthritis. Clinical Medicine Research 2014;2:25-30. 
9. Kellgren JH, Lawrence JS. Radiological assessment of osteoarthrosis. Ann Rheum Dis 1957;16: 494502.

10. American College of Rheumatology Subcommittee on Osteoarthritis. Recommendations for the medical management of osteoarthritis of the hip and knee. 2000 update. Arthritis Rheum 2000;43: 1905-15.

11. Wewers ME, Lowe NK. A critical review of visual analogue scales in the measurement of clinical phenomena. Res Nurs Health 1990;13: 227-36.

12. Bellamy N, Buchanan WW, Goldsmith CH, Campbell J, Stitt LW. Validation study of WOMAC: A health status instrument for measuring clinically important patient relevant outcomes to antirheumatic drug therapy in patients with osteoarthritis of the hip or knee. J Rheumatol 1988;15: 1833-40.

13. Tuzun EH, Eker L, Aytar A, Daşkapan A, Bayramoğlu M. Acceptability, reliability, validity and responsiveness of the Turkish version of WOMAC osteoarthritis index. Osteoarthritis Cartilage 2005;13: 28-33.

14. Lequesne MG, Samson S. Indices of severity in osteoarthritis for weight bearing joints. J Rheumatol Suppl 1991;27:16-8.

15. Faucher M, Poiraudeau S, Lefevre-Colau MM, Rannou F, Fermanian J, Revel M. Assessment of the test-retest reliability and construct validity of a modified Lequesne index in knee osteoarthritis. Joint Bone Spine 2003;70: 521-5.

16. Basaran S, Guzel R, Seydaoglu G, Guler-Uysal F. Validity, reliability, and comparison of the WOMAC osteoarthritis index and Lequesne algofunctional index in Turkish patients with hip or knee osteoarthritis. Clin Rheumatol 2010;29: 749-56.

17. Buysse DJ, Reynolds CF 3rd, Monk TH, Berman SR, Kupfer DJ. The Pittsburgh Sleep Quality Index: a new instrument for psychiatric practice and research. Psychiatry Res 1989;28: 193-213.

18. Ağargün MY, Kara H, Anlar Ö. Pittsburgh Uyku Kalitesi Indeksi'nin geçerliği ve güvenirliği. Türk Psikiyatri Dergisi 1996;7:107-15.

19. Koçyiğit H, Aydemir Ö, Fișek G, Ölmez N, Memiș A. Kısa Form-36 (KF 36)'nın Türkçe versiyonunun güvenilirliği ve geçerliliğ̆i. İlaç ve Tedavi Dergisi 1999;12:102-6.

20. Beck AT, Ward CH, Mendelson M, Mock J, Erbaugh J. An inventory for measuring depression. Arch Gen Psychiatry 1961;4:561-71.

21. Ulusoy M, Şahin N, Erkman H. Turkish Version of The Beck anxiety inventory: psychometric properties. J Cognitive Psychotherapy: Int Quaterly 1998;12:28-35.

22. Sayar K, Kirmayer LJ, Taillefer SS. Predictors of somatic symptoms in depressive disorder. Gen Hosp Psychiatry 2003;25: 108-14.

23. Keefe FJ, Lefebvre JC, Egert JR, Affleck G, Sullivan MJ, Caldwell DS. The relationship of gender to pain, pain behavior and disability in osteoarthritis patients: the role of catastrophizing. Pain 2000;87:325-34.

24. Meana M. The meeting of pain and depression: comorbidity in women. Can J Psychiatry 1998;43: 893-9.

25. Iijima H, Aoyama T, Fukutani N, et al. Psychological health is associated with knee pain and physical function in patients with knee osteoarthritis: an exploratory cross-sectional study. BMC Psychology 2018;6:19. doi:10.1186/s40359-018-0234-3.

26. Supartini A, Oishi T, Yagi N. Sex Differences in the relationship between sleep behavior, fish consumption, and depressive symptoms in the general population of South Korea. Int J Environ Res Public Health 2017;14. pii: E789. doi: 10.3390/ijerph14070789.

27. Creamer P, Lethbridge-Cejku M, Hochberg MC. Factors associated with functional impairment in symptomatic knee osteoarthritis. Rheumatology (Oxford) 2000;39: 490-6.

28. Aşkın A, Özkan A, Tosun A, Demirdal ÜS, İsnaç F. Quality of life and functional capacity are adversely affected in osteoarthritis patients with neuropathic pain. Kaohsiung J Med Sci 2017;33: 152-8. 